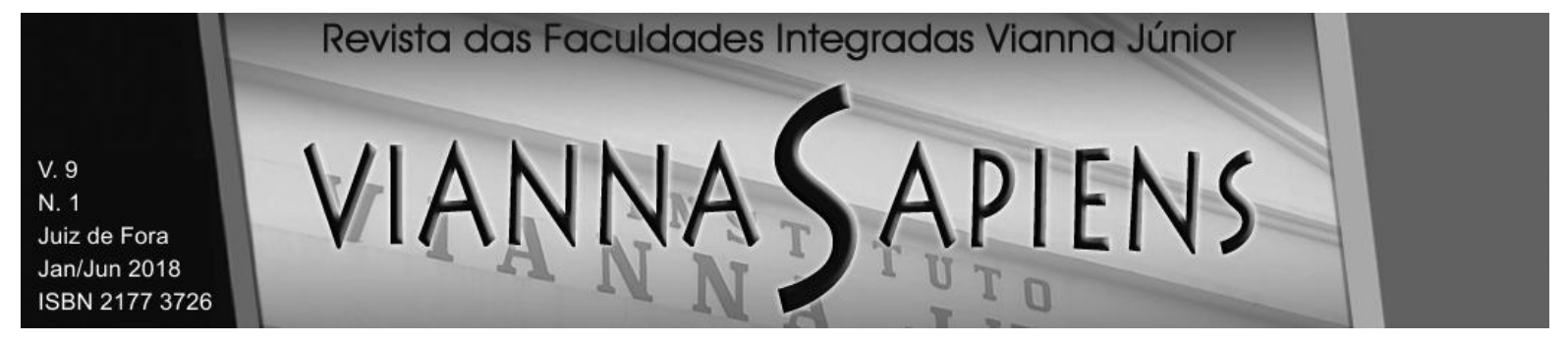

\title{
A NECESSIDADE DE INTERPRETAÇÃO CONFORME A CONSTITUIÇÃO DO ARTIGO 170-A DO CÓDIGO TRIBUTÁRIO NACIONAL
} DOI: 10.31994/rvs.v9i1.266

Sonia Leal Martins ${ }^{1}$

\section{RESUMO}

O artigo 170-A introduzido no Código Tributário Nacional pela Lei Complementar 104/2001 veda expressamente a compensação tributária antes do trânsito em julgado da decisão em que se pleiteia o reconhecimento do indébito. Em outros termos, o referido artigo não permite medida liminar para compensação de créditos tributários nas ações mandamentais ou tutela de urgência nas ações ordinárias de repetição de indébito. Nessa esteira, o presente trabalho tem como objetivo demonstrar a necessidade de uma interpretação do artigo 170-A conforme a Constituição Federal nos casos em que o contribuinte tem a seu favor uma decisão em sede de repercussão geral ou recurso repetitivo, não se justificando mais esperar o trânsito em julgado para então compensar o indébito tributário. A metodologia utilizada foi a pesquisa bibliográfica e documental baseada em revistas e livros atualizados, bem como na jurisprudência e legislação pátria. Por fim, concluiu-se ser

\footnotetext{
${ }^{1}$ Bacharel em Direito pelas Faculdades Integradas Vianna Júnior; Bacharel em Ciências Contábeis e Especialista em Contabilidade Tributária pela Faculdade Machado Sobrinho; Especialista em Direito Tributário pela Universidade Estácio de Sá; Pós-Graduanda em Direito Processual e em Direito Constitucional pela Faculdade de Estudos Administrativos de Minas Gerais. Advogada. Contadora do Instituto Federal de Ciência e Tecnologia do Sudeste de Minas Gerais - Campus Juiz de Fora. e-mail: soniamartins2802@gmail.com; https://orcid.org/0000-0002-4085-5260;
} 


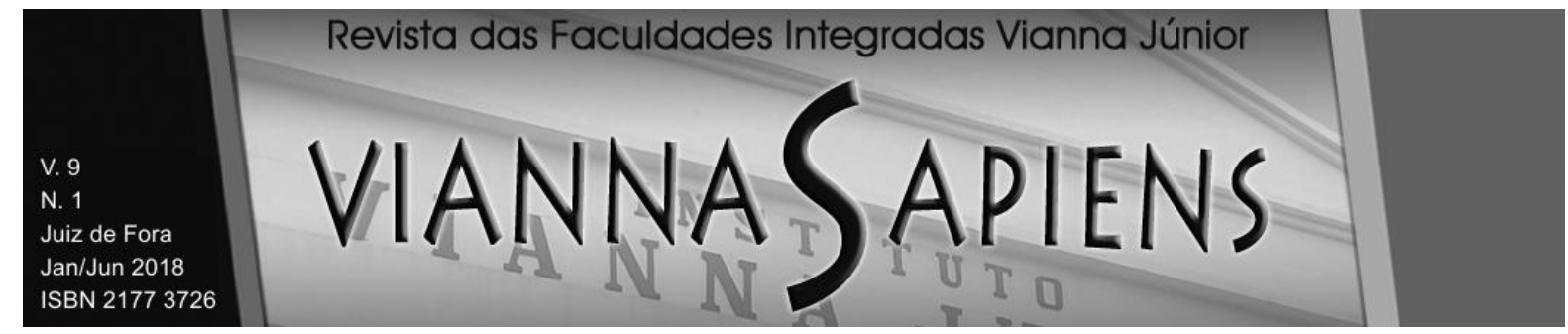

possível a concessão da antecipação dos efeitos da sentença nos casos em que o contribuinte tem a seu favor um precedente de natureza vinculativa.

\section{PALAVRAS-CHAVE: ARTIGO 170-A. CÓDIGO TRIBUTÁRIO NACIONAL. COMPENSAÇÃO TRIBUTÁRIA}

\section{INTRODUÇÃO}

O artigo 170-A foi introduzido pela Lei Complementar 104/2001(BRASIL, 2001) no Código Tributário Nacional (BRASIL, 1966) com a finalidade de coibir as compensações tributárias antes do trânsito em julgado da decisão em que está sendo pleiteado o reconhecimento do indébito. Na época em que o referido artigo foi editado, eram muito comuns decisões que permitiam a compensação por meio de liminar ou tutela de urgência e que posteriormente, a decisão transitada em julgado, não reconhecia o direito ao indébito tributário, o que provocava prejuízos para a Fazenda Pública.

A Emenda Constitucional ㄲo 45/2004 (BRASIL, 2004) introduziu uma série de garantias fundamentais, entre elas, a razoável duração do processo e os meios que garantem a celeridade de sua tramitação prevista no artigo $5^{\circ}$ inciso LXXVIII da Constituição Federal (BRASIL, 1988).

A Lei 11.418/06 (BRASIL, 2006) trouxe mecanismos para a efetivação do direito fundamental à razoável duração do processo e celeridade de sua tramitação. Nesse diapasão, foram introduzidos no Código de Processo Civil de 1973 (BRASIL, 1973) os institutos da repercussão geral no Supremo Tribunal Federal por meio do artigo 543-B e dos recursos repetitivos no Superior Tribunal de Justiça por meio do artigo 543-C.

O novo Código de Processo Civil (BRASIL, 2015) não só manteve a sistemática dos recursos extraordinário e especial repetitivos nos artigos 1.036 a 1.041, como também reafirmou a necessidade de valorização dos precedentes 


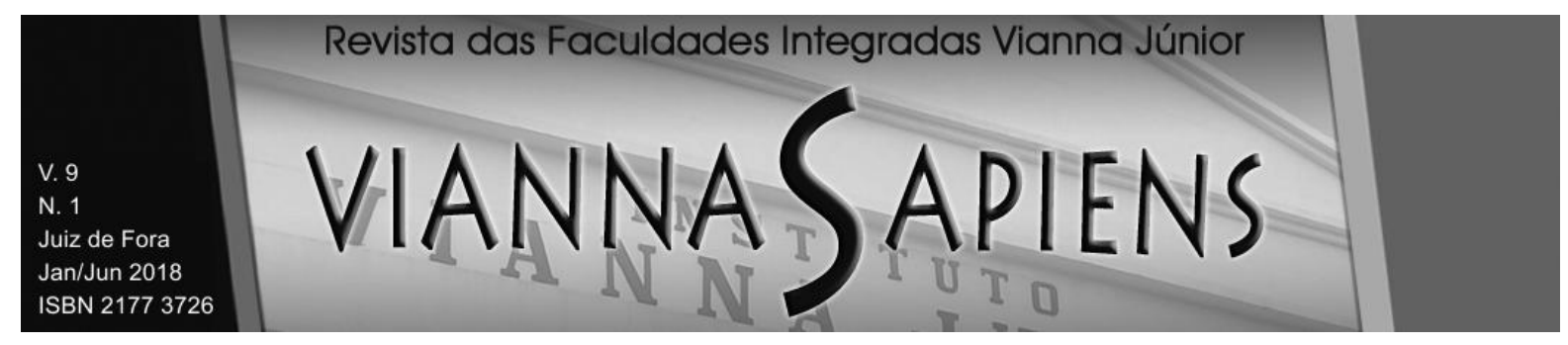

judiciais ao criar o "incidente de resolução de demandas repetitivas" no capítulo VIII do Livro III.

Nessa esteira, o presente trabalho tem como objetivo demonstrar a necessidade de uma interpretação do artigo 170-A conforme a Constituição Federal nos casos em que o contribuinte tem a seu favor uma decisão em sede de repercussão geral ou recurso repetitivo, não se justificando mais esperar o trânsito em julgado para então compensar o indébito tributário. A metodologia utilizada será a pesquisa bibliográfica e documental baseada em revistas e livros atualizados, bem como na jurisprudência e legislação pátria.

O trabalho será feito buscando-se, a partir dessa introdução, demonstrar a relevância do tema tendo-se em vista que a vedação à compensação antes do trânsito em julgado foi editada antes da criação da sistemática dos recursos extraordinário e especial repetitivos, o que justifica, nos dias atuais, uma interpretação do referido dispositivo conforme a constituição, relativizando o seu alcance em certos casos. Em seguida, serão feitas breves considerações dividindose o estudo em quatro partes: a primeira parte tratará do instituto da compensação e das suas regras em matéria tributária no âmbito federal. A segunda parte trará breves considerações sobre a vedação imposta pelo artigo 170-A do Código Tributário Nacional. A terceira parte tratará da valorização dos precedentes e da sistemática dos recursos extraordinário e especial repetitivos. Por fim, a quarta parte fará uma análise da necessidade de interpretação do artigo 170-A do Código Tributário Nacional conforme a Constituição Federal ante a existência de decisão favorável ao contribuinte em sede de recursos extraordinário e especial repetitivo.

\section{A COMPENSAÇÃO TRIBUTÁRIA NA ESFERA FEDERAL}

O artigo 368 do Código Civil (BRASIL, 2002) traz a possibilidade de compensação na esfera civil: "Se duas pessoas forem ao mesmo tempo credor e devedor uma da outra, as duas obrigações extinguem-se, até onde se 


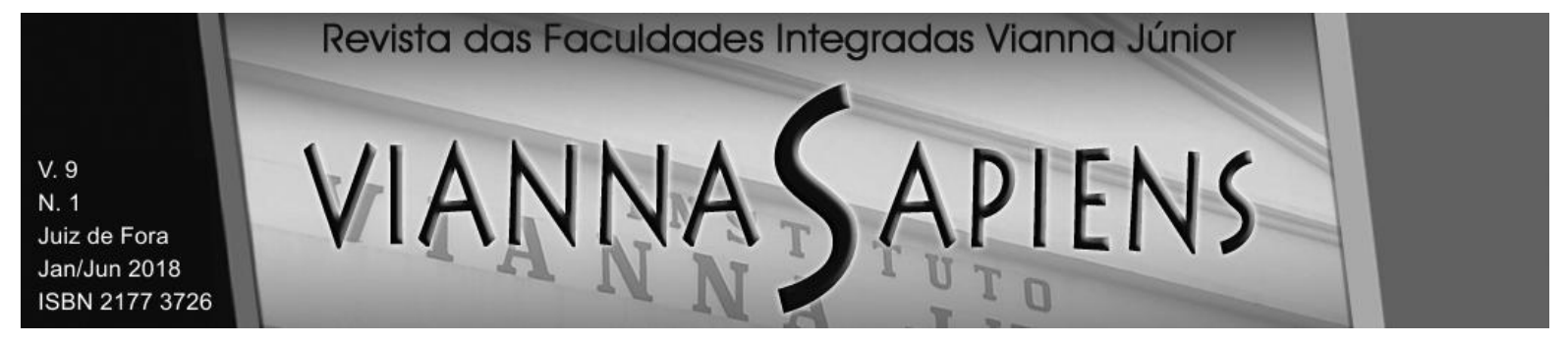

compensarem". Insta salientar que nos termos do artigo 369, a liquidez e a exigibilidade atual das dívidas bem como a fungibilidade são requisitos necessários à possibilidade da compensação civil.

José Eduardo Soares de Melo (2007, p. 340) traz importante ensinamento sobre o instituto da compensação:

Funda-se na justiça e na equidade, revelando significativa utilidade, pois objetiva (implicitamente) evitar a multiplicação de providências administrativas e demandas judiciais. Notória a vantagem da compensação na medida em que inúmeras transações se entrecruzam em sentidos diversos. Dessa forma, poupam-se várias complicações e ônus, em razão da simples amortização dos créditos recíprocos, eliminando-se repetidas transferências ou movimentações de dinheiro e os naturais riscos de atrasos perdas, etc

A compensação tributária, diferentemente da compensação civil, exige lei autorizando-a. Nessa esteira, o artigo 170 do Código Tributário Nacional (BRASIL, 1966) determina:

A lei pode, nas condições e sob as garantias que estipular, ou cuja estipulação em cada caso atribuir à autoridade administrativa, autorizar a compensação de créditos tributários com créditos líquidos e certos, vencidos ou vincendos, do sujeito passivo contra a Fazenda pública. (Grifo nosso)

Nesse sentido, a compensação tributária se difere da compensação civil, pois aquela exige lei que a autorize, além de possibilitar a compensação não somente dos créditos vencidos, mas também dos créditos vincendos. Já a compensação civil, como dito anteriormente, pode se dar de maneira automática desde que os créditos estejam vencidos.

Para Maria Helena Diniz (2007, p.311), a compensação legal resulta na:

[...] extinção de obrigações recíprocas, liberando os devedores e retroagindo à data em que a situação fática se configurou. Dessa forma, a pesar de ter sido alegada posteriormente, operará (ipso jure) 


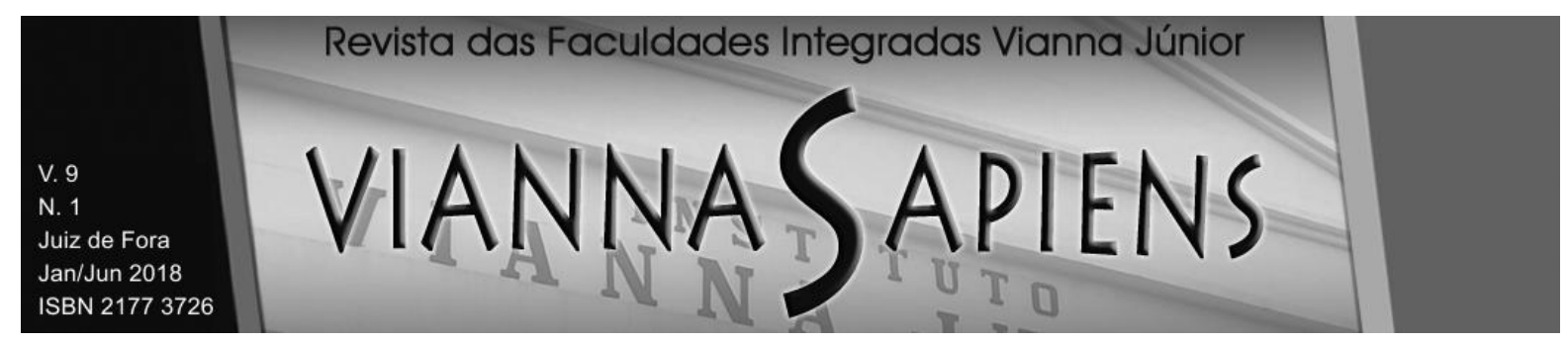

desde o instante em que o réu, cobrado de uma prestação, se tornar credor do autor. Tal efeito retroativo alcança ambas as dívidas, com todos os seus acessórios, de modo que os juros e as garantias do crédito deixam de existir a partir do momento em que se tiver a coexistência de dívidas.

$\mathrm{Na}$ esfera federal, pode-se verificar a existência de dois sistemas de compensação de tributos: um sistema para compensação de contribuições previdenciárias previsto na Lei no 8.383/91 (BRASIL, 1991) e outro previsto na Lei no 9.430/96 (BRASIL, 1996) para a compensação de indébitos dos demais tributos federais.

A sistemática de compensação prevista no parágrafo $1^{\circ}$ do artigo 66 da Lei $\mathrm{n}^{\circ}$ 8.383/91 (BRASIL, 1991) permite a compensação entre "tributos, contribuições e receitas da mesma espécie”. Insta salientar, que após a edição da Lei n 9.430/96, esse regime é permitido somente para a compensação das contribuições previdenciárias.

Já a Lei no 9.430/96, diferentemente da Lei $n-0$ 8.383/91, permite a compensação entre quaisquer tributos e contribuições administrados pela Receita Federal do Brasil, excluindo-se as contribuições previdenciárias (que na época da sua edição, eram administrados pelo INSS - Instituto Nacional do Seguro Social). Nesse sentido, o artigo 74 da Lei no 9.430/96 (BRASIL, 1996) aduz:

O sujeito passivo que apurar crédito, inclusive os judiciais com trânsito em julgado, relativo a tributo ou contribuição administrado pela Secretaria da Receita Federal, passível de restituição ou de ressarcimento, poderá utilizá-lo na compensação de débitos próprios relativos a quaisquer tributos e contribuições administrados por aquele Órgão.

Atualmente a Receita Federal do Brasil administra também as contribuições previdenciárias, nos termos da Lei n 11.457/07. Entretanto, estas continuam sendo regidas pela Lei $n^{\circ}$ 8.383/91, tendo-se em vista que a Lei $n^{\circ}$ 9.430/96 teve sua abrangência restrita aos tributos ou contribuições administrados pela Receita Federal do Brasil na época de sua edição. 


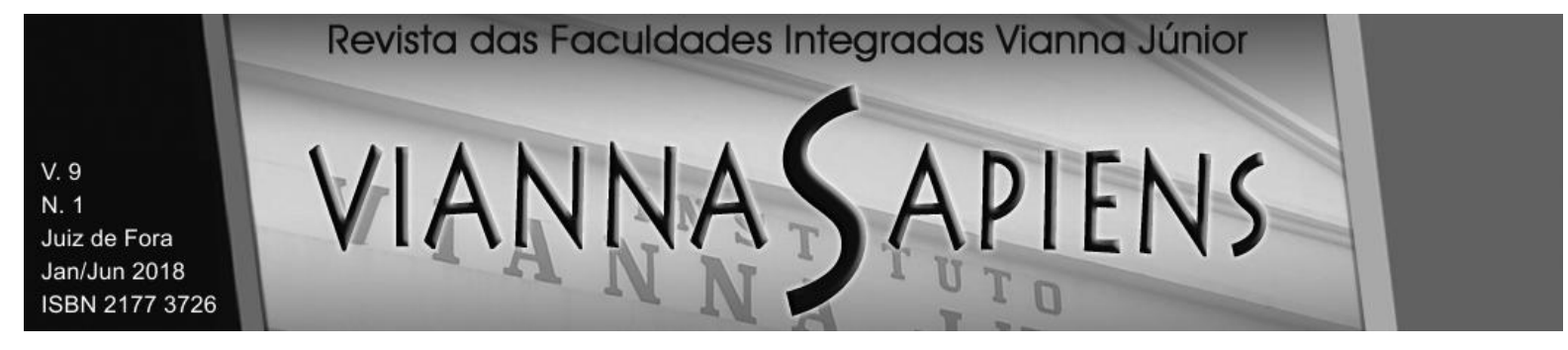

Cumpre destacar que a compensação das contribuições previdenciárias se dá de forma direta onde o contribuinte informa em suas obrigações acessórias o valor das contribuições pagas indevidamente, bem como os valores das obrigações vencidas ou vincendas em que se deseja extinguir por meio da compensação. Cabe à Receita Federal verificar posteriormente a regularidade das informações.

Já a compensação dos demais tributos se dá por meio da entrega de declaração com a descrição dos valores representativos do indébito, bem como dos valores das obrigações que se pretende extinguir por meio da compensação. É o que determina o parágrafo $1^{\circ}$ do artigo 74 da Lei no 9.430/96 (BRASIL, 1996): "A compensação de que trata o caput será efetuada mediante a entrega, pelo sujeito passivo, de declaração na qual constarão informações relativas aos créditos utilizados e aos respectivos débitos compensados".

Importante destacar que a extinção do crédito tributário, nessa modalidade de compensação, se dará em condição resolutória da ulterior homologação da entrega da declaração de compensação que deverá ocorrer em até cinco anos nos termos dos parágrafos $2^{\circ}$ e 5ำ do artigo 74 da Lei ำ 9.430/96 (BRASIL, 1996).

A homologação da declaração de compensação poderá se dar de forma expressa ou tácita. Além disso, poderá ser indeferida ou considerada não declarada nos casos previstos no parágrafo 12 do artigo 74 da Lei nำ 9.430/96 (BRASIL, 1996).

Sendo a homologação expressa ou tácita, tem-se a extinção do crédito tributário de acordo a previsão do artigo 156 do Código Tributário Nacional (BRASIL, 1966) que traz em seu inciso II a compensação como hipótese de extinção do crédito tributário.

Nos casos em que a compensação for indeferida, total ou parcialmente, o contribuinte tem a opção de apresentar manifestação de inconformidade e, caso essa manifestação seja julgada improcedente, poderá recorrer ao Conselho de Contribuintes nos termos dos parágrafos $9^{\circ}$ e $10^{\circ}$ do artigo 74 da Lei $n^{\circ}$ 9.430/96 (BRASIL, 1996).

Por fim, sendo a compensação considerada não declarada, o contribuinte não poderá apresentar a manifestação de inconformidade de acordo com o parágrafo 13 


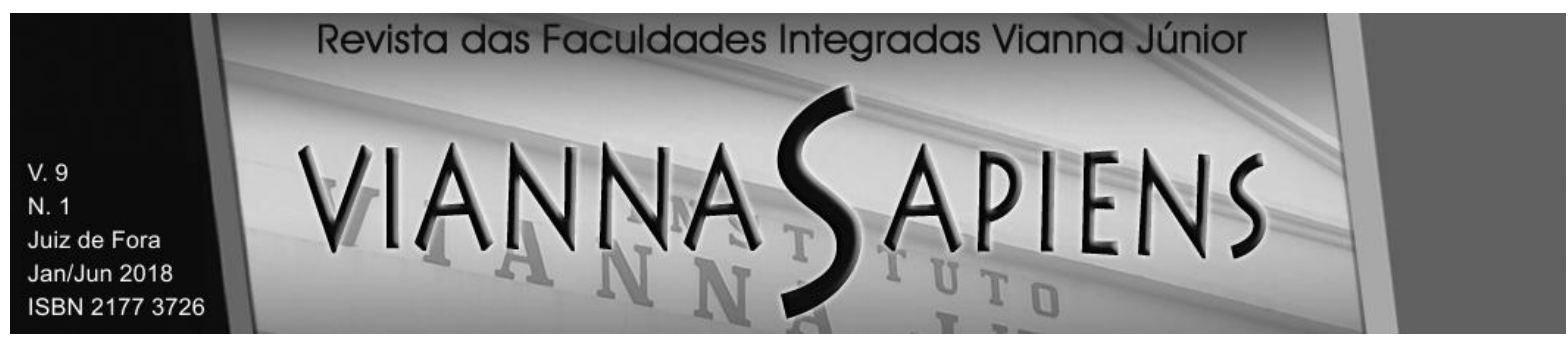

do referido artigo 74, restando ao mesmo, somente a via judicial para pleitear 0 reconhecimento do indébito tributário.

\section{A VEDAÇÃO DO ARTIGO 170-A DO CÓDIGO TRIBUTÁRIO NACIONAL}

Como dito anteriormente, quando o contribuinte pleiteia administrativamente a compensação tributária e a Receita Federal a considera como "não declarada", não terá a opção de apresentar manifestação de inconformidade, restando ao mesmo valer-se do poder judiciário a fim de obter o reconhecimento do indébito tributário.

Ocorre que, antes da inclusão do artigo 170-A no Código Tributário Nacional em 2001, era recorrente o deferimento de tutela de urgência antecipando a compensação tributária que posteriormente era tida como indevida em virtude do não reconhecimento do indébito tributário. Tal procedimento causava transtornos e prejuízos para a Fazenda Pública. Nesse cenário, a Lei Complementar nº 104/2001 introduziu no Código Tributário Nacional o artigo 170-A que veda "a compensação mediante o aproveitamento de tributo, objeto de contestação judicial pelo sujeito passivo, antes do trânsito em julgado da respectiva decisão judicial”.

Importante destacar que as diversas ações que tramitavam no judiciário dando origem à inclusão do referido artigo 170-A no Código Tributário Nacional, não tratavam do direito à compensação em si, mas da discussão em torno da constitucionalidade da regra-matriz do tributo. Nesse sentido, Paulo César Conrado (2016, p. 517-518):

Reportando-se a 2001, referido preceito operava, ao tempo de seu nascimento, sobre contexto normativo bem diverso do atual, caracterizado, em suma, pela submissão da prática compensatória à prévia aprovação administrativa. Em sua lógica, indigitado regime colocava nas mãos do contribuinte o encargo de requerer, administrativamente, o aproveitamento de indébitos previamente assentados para fins de quitação de obrigação tributária pendente, com o consequente efeito prescrito no art. 156, inciso II, do Código Tributário Nacional. Comuns sempre se mostraram, porém, situações em que o indébito a compensar não se encontraria prontamente 


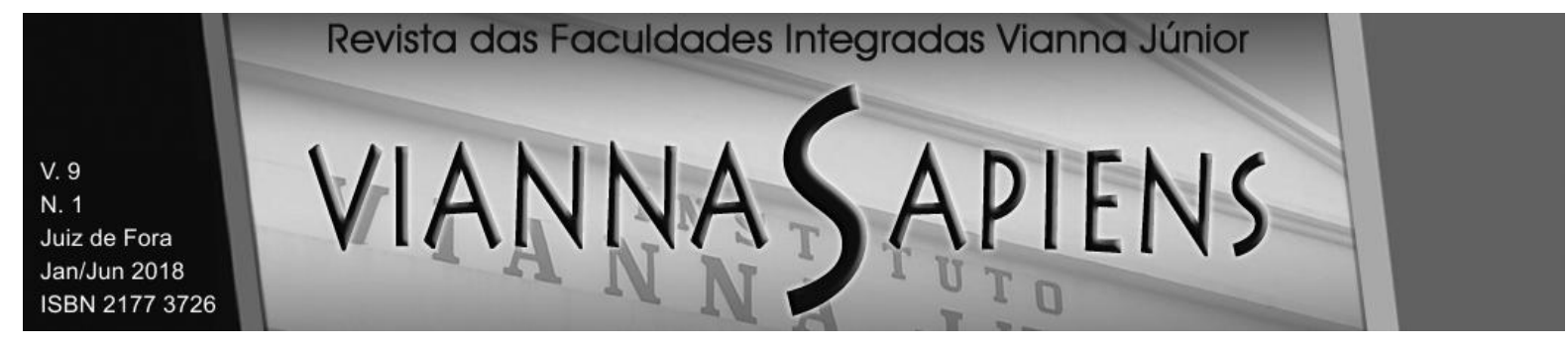

reconhecível, demandando o enfrentamento de questões de direito como, por exemplo, a tomada como inconstitucional da regra matriz de incidência - administrativamente incognoscíveis. Aí o porquê da repetida judicialização de muitos casos relacionados à figura da compensação. Note-se, de todo modo, que boa parte desses "casos judicializados" não tinha (nem nunca teve) muito que ver com o direito à compensação em si mesmo considerado, senão com sua premissa, o indébito. Especulava-se, usando outros termos, sobre qual(is) meio(s) de constituição do citado fato jurídico (o indébito) seria $(m)$, para aquele fim (da compensação), validável(is). Esse era (e é) o problema que reiteradamente se punha/põe; e foi nesse contexto que se assentou, depois de intensos debates jurisprudenciais (que desaguaram, sabe-se, na produção da Súmula 212 do Superior Tribunal de Justiça), o tal art. 170-A no Código Tributário Nacional. A lógica desse dispositivo, quando posto em projeção histórica, é irrecusável: se o indébito era (e é, repise-se) condição para a efetivação da compensação tributária, natural que, tendo sido judicializado seu reconhecimento, a admissão da prática compensatória (com o consequente efeito extintivo preconizado pelo já mencionado art. 156) devesse ficar adstrita ao trânsito em julgado da respectiva sentença.

Tendo em vista a inclusão do Artigo 170-A no Código Tributário Nacional, foi introduzida a alínea "d" no parágrafo 12 do artigo 74 da lei n 9.430/96 (BRASIL, 1996) onde determina que a Receita Federal do Brasil deverá considerar como não declarada a compensação que "seja decorrente de decisão judicial não transitada em julgado".

Nesse diapasão, o impedimento da compensação tributária antes do trânsito em julgado se justifica quando o cenário é de incerteza no que tange ao direito alegado pelo contribuinte. Em outras palavras, é preciso interpretar o artigo 170-A restringindo o seu alcance aos casos em que não há decisão em sede de recurso extraordinário e especial repetitivo, como será visto mais detalhadamente em momento oportuno. 


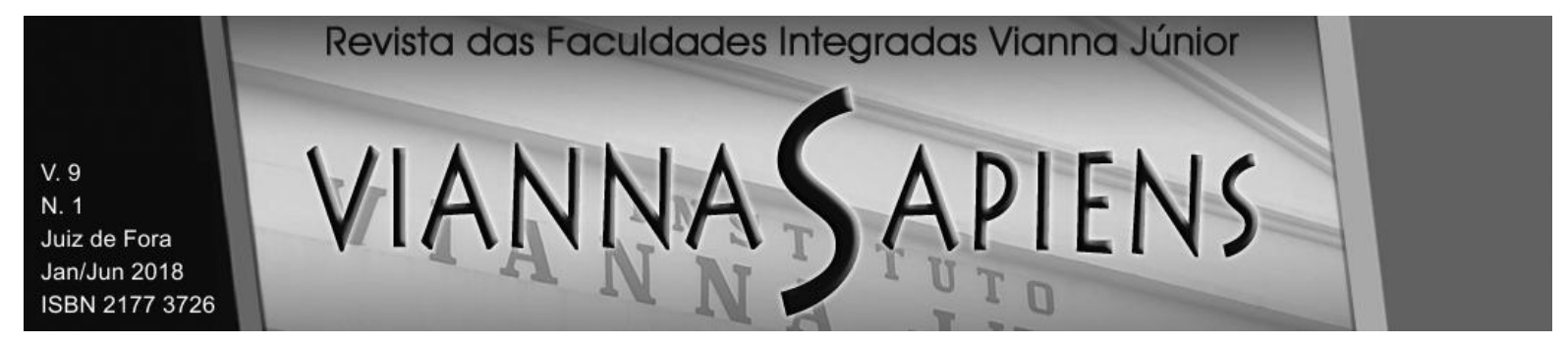

\section{A VALORIZAÇÃo do PRECEDENTE E A SISTEMÁtICA dOS RECURSOS EXTRAORDINÁRIO E ESPECIAL REPETITIVOS}

Nas últimas décadas o legislador tem se preocupado com o número crescente de demandas judiciais e a consequente morosidade da solução da lide. Nesse sentido, é patente a necessidade de adoção de mecanismos que possibilitem o cumprimento do direito fundamental à duração razoável do processo.

A valorização do precedente tem sido cada vez maior, tendo-se em vista que por meio da vinculação das decisões, acelera-se de maneira substancial a solução da lide, além de viabilizar o respeito aos princípios da isonomia e da segurança jurídica.

Sobre a importância dos precedentes, Marcus Abraham (2014, p. 159-160) leciona:

Além do ganho em celeridade processual, agora alçada a direito fundamental pela Constituição, busca-se evitar o deletério efeito de haver decisões em sentido contrário em hipóteses idênticas. Nada desaponta mais o cidadão a quem se nega uma tutela jurisdicional que ver o seu concidadão ter o direito reconhecido pelo Poder Judiciário, em situação idêntica, enquanto o seu direito foi rechaçado. O potencial de pacificação social ínsito na eficácia uniformizadora, isonômica e estabilizadora destes novos métodos não é desprezível, mormente em razão de que, como ensina a Teoria Geral do Processo, é função precípua da prestação jurisdicional buscar a paz social por meio da composição dos litígios.

Importa salientar que o termo precedente tem um significado distinto de jurisprudência. Nesse sentido, Araújo, (2016, p. 111):

Comumente, os termos jurisprudência e precedente são utilizados como enunciados que apresentam a mesma significação. Apesar de se constituírem em realidades próximas, são distintos.

Ao falarmos em jurisprudência, estamos nos referindo a um a conjunto de julgados em um mesmo sentido que expressam o entendimento de um determinado tribunal. São várias decisões que encerram um pronunciamento judicial que se aplica de forma indistinta a situações semelhantes. Reflete, portanto, a ideia de quantidade de julgados que apontam para um determinado sentido. 


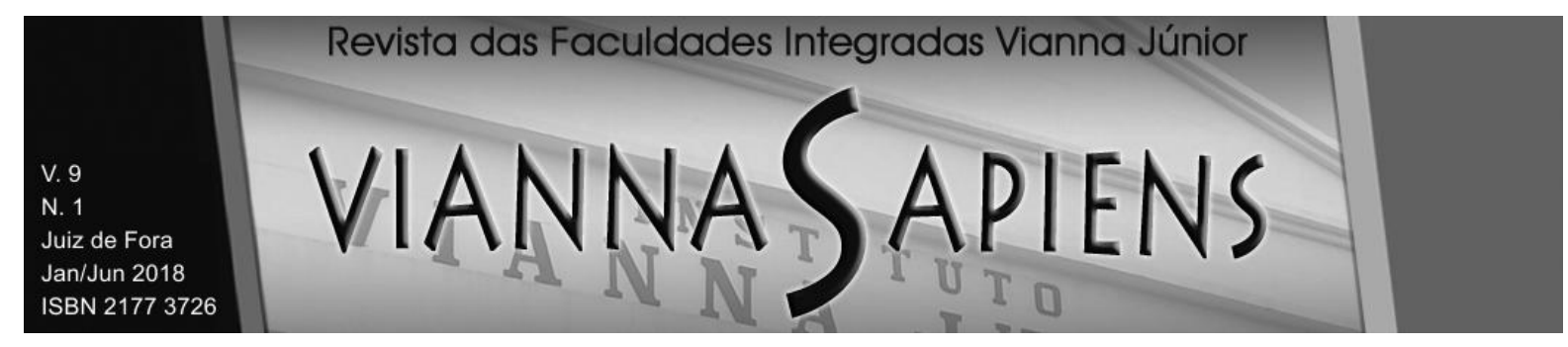

Já o precedente, em um sentido amplo, seria uma decisão proveniente do Poder Judiciário que tem força suficiente para influenciar a solução de casos futuros. Portanto, teria consistência e autoridade para servir de referência e pautar as condutas semelhantes a serem definidas pelos tribunais.

Nesse diapasão, a jurisprudência pode ser entendida como uma tendência adotada por um determinado tribunal sobre um determinado assunto. Já o precedente representa a decisão de um processo paradigma que tem força vinculante, não podendo as instâncias inferiores decidir de forma divergente quando se tratar de casos semelhantes.

A súmula vinculante introduzida no artigo 103-A da Constituição Federal de 1988 (BRASIL, 1988) por meio da Emenda Constitucional n 45/2001 (BRASIL, 2001), foi um dos primeiros mecanismos criados para valorização do precedente judicial. Pouco tempo depois, a Lei $n^{\circ} 11.418 / 06$ (BRASIL, 2006) introduziu no Código de Processo Civil de 1973 (BRASIL, 1973) os artigos 543-B e 543-C que tratam da sistemática dos recursos extraordinário e especial repetitivos.

O novo Código de Processo Civil (BRASIL, 2015) reforçou a valorização dos precedentes ao introduzir mecanismos que contribuem para a uniformização da jurisprudência, como é o caso da criação do Incidente de Resolução de Demandas Repetitivas previsto nos artigos 976 e seguintes. Além disso, manteve a sistemática dos recursos extraordinários e especiais repetitivos trazendo importantes modificações em seu procedimento.

Nesse sentido, o novo Código de Processo Civil determina em seu artigo 926 (BRASIL, 2015) que "os tribunais devem uniformizar sua jurisprudência e mantê-la estável, íntegra e coerente".

Além disso, o novo códex, em seu artigo 927 (BRASIL, 2015) determina:

Art. 927. Os juízes e os tribunais observarão:

I - as decisões do Supremo Tribunal Federal em controle concentrado de constitucionalidade;

II - os enunciados de súmula vinculante; 


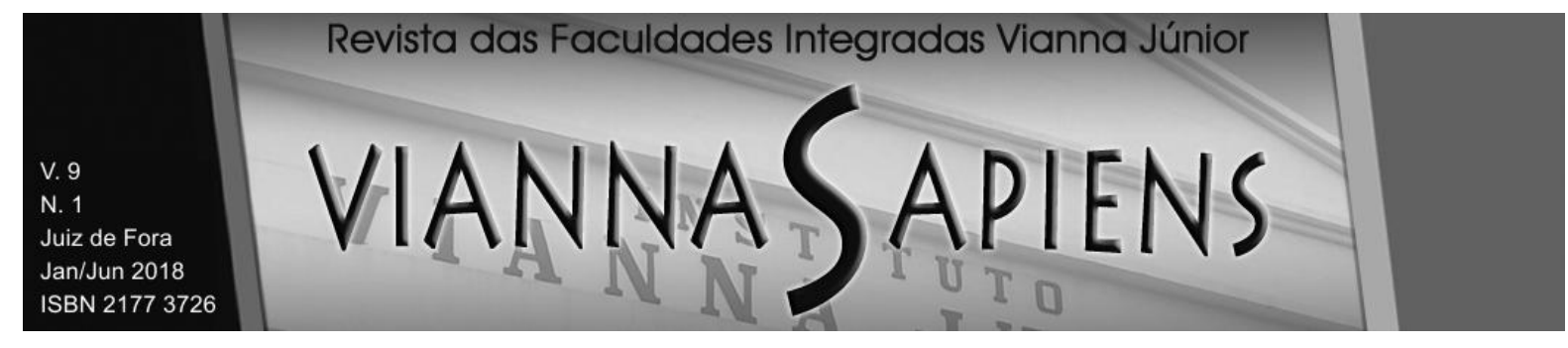

III - os acórdãos em incidente de assunção de competência ou de resolução de demandas repetitivas e em julgamento de recursos extraordinário e especial repetitivos;

IV - os enunciados das súmulas do Supremo Tribunal Federal em matéria constitucional e do Superior Tribunal de Justiça em matéria infraconstitucional;

V - a orientação do plenário ou do órgão especial aos quais estiverem vinculados.

$\S 1^{\circ}$ Os juízes e os tribunais observarão o disposto no art. 10 e no art. 489, $\S 1^{\circ}$, quando decidirem com fundamento neste artigo.

$\S 2^{\circ} \mathrm{A}$ alteração de tese jurídica adotada em enunciado de súmula ou em julgamento de casos repetitivos poderá ser precedida de audiências públicas e da participação de pessoas, órgãos ou entidades que possam contribuir para a rediscussão da tese.

$\S 3^{\circ} \mathrm{Na}$ hipótese de alteração de jurisprudência dominante do Supremo Tribunal Federal e dos tribunais superiores ou daquela oriunda de julgamento de casos repetitivos, pode haver modulação dos efeitos da alteração no interesse social e no da segurança jurídica.

$\S 4^{\circ} \mathrm{A}$ modificação de enunciado de súmula, de jurisprudência pacificada ou de tese adotada em julgamento de casos repetitivos observará a necessidade de fundamentação adequada e específica, considerando os princípios da segurança jurídica, da proteção da confiança e da isonomia.

$\S 5^{\circ}$ Os tribunais darão publicidade a seus precedentes, organizando-os por questão jurídica decidida e divulgando-os, preferencialmente, na rede mundial de computadores.

No mesmo sentido, o inciso $\mathrm{VI}$ do parágrafo $1^{\circ}$ do artigo 489 do mesmo diploma (BRASIL, 2015) considera não fundamentada qualquer decisão que "deixar de seguir enunciado de súmula, jurisprudência ou precedente invocado pela parte, sem demonstrar a existência de distinção no caso em julgamento ou a superação do entendimento".

Nesse diapasão, o novo Código de Processo Civil traz os requisitos para a formação e vinculação dos precedentes nos artigos 926, 927 e 489 parágrafo $1^{\circ}$ de forma que caberá à parte interessada demonstrar que se trata de caso semelhante e invocar a observância do precedente pelo órgão julgador.

No que tange à sistemática dos recursos extraordinário e especial repetitivo, 0 novo Código de Processo Civil regulamentou o procedimento nos seus artigos 1.036 a 1.041 (BRASIL, 2015).

Nos termos do artigo 1.036 (BRASIL, 2015): 


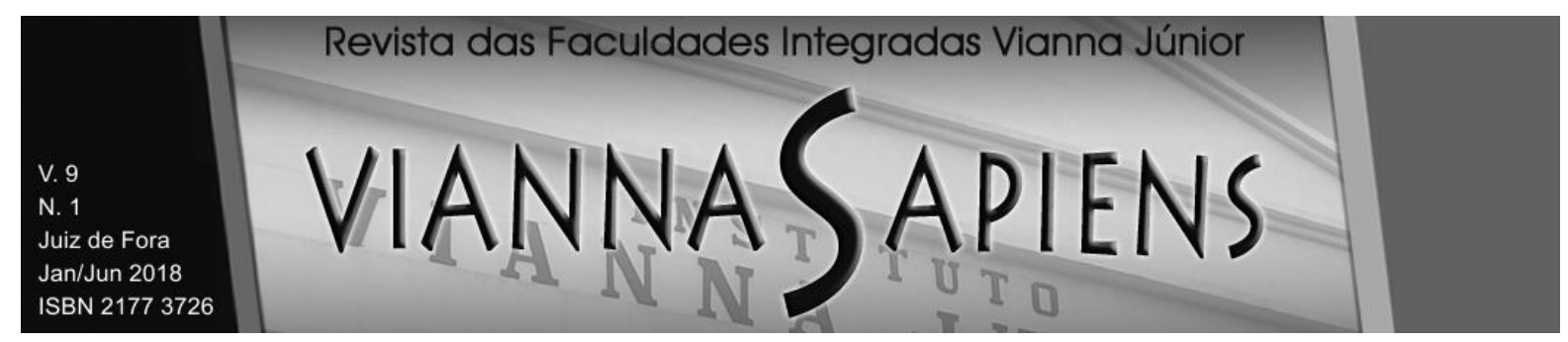

Art. 1.036. Sempre que houver multiplicidade de recursos extraordinários ou especiais com fundamento em idêntica questão de direito, haverá afetação para julgamento de acordo com as disposições desta Subseção, observado o disposto no Regimento Interno do Supremo Tribunal Federal e no do Superior Tribunal de Justiça.

Nos termos do parágrafo $1^{\circ}$ do artigo 1.036 do novo código de Processo Civil (BRASIL, 2015), o presidente ou o vice-presidente de Tribunal de Justiça ou Tribunal Regional Federal, encaminhará para ao Supremo Tribunal Federal ou ao Superior Tribunal de Justiça 2 (dois) ou mais recursos representativos da controvérsia. Além disso, determinará a suspensão do trâmite de todos os processos pendentes, individuais ou coletivos que tramitem na jurisdição do Tribunal.

Insta salientar que de acordo com os parágrafos $4^{\circ}$ e $5^{\circ}$ do mesmo artigo, o relator nos tribunais superiores também poderá proceder com a afetação de recursos, independente da escolha feita pelos tribunais inferiores.

Após a seleção dos recursos, nos termos do artigo 1.037 (BRASIL, 2015):

Art. 1.037. Selecionados os recursos, o relator, no tribunal superior, constatando a presença do pressuposto do caput do art. 1.036, proferirá decisão de afetação, na qual:

I - identificará com precisão a questão a ser submetida a julgamento;

II - determinará a suspensão do processamento de todos os processos pendentes, individuais ou coletivos, que versem sobre a questão e tramitem no território nacional;

III - poderá requisitar aos presidentes ou aos vice-presidentes dos tribunais de justiça ou dos tribunais regionais federais a remessa de um recurso representativo da controvérsia.

Nesse sentido, sendo acatada a afetação, o relator determinará a suspensão de todos os processos que versem sobre a mesma questão tramitando no território nacional.

Após o julgamento, dar-se-á seguimento aos processos suspensos com a observância de aplicação da tese jurídica definida pelos Tribunais Superiores, nos 


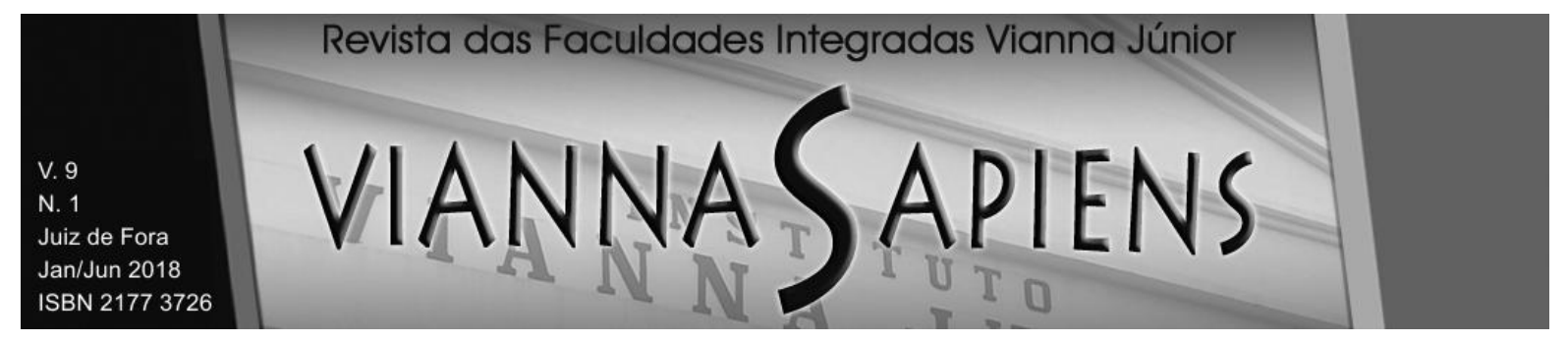

termos do inciso III do artigo 1.040 do novo código de Processo Civil (BRASIL, 2015).

Como dito anteriormente, o novo códex trouxe importantes modificações na sistemática de julgamento dos recursos repetitivos. Tendo em vista o escopo desse trabalho, cabe destacar dentre essas alterações, o fato de que a vinculação no sistema atual passa a ser em relação a todas as instâncias, o que não acontecia no regime anterior. Isso porque de acordo com os artigos 543-B e 543-C do Código de Processo Civil de 1973 (BRASIL, 1973), somente os processos em sede de recursos eram sobrestados durante a análise do recurso paradigma. Além disso, não havia nenhum dispositivo que vinculasse expressamente os juízes de primeira instância. Em sentido contrário, o caput do artigo 927 do novo Código de Processo Civil (BRASIL, 2015) vincula expressamente as decisões dos juízes e dos tribunais. Ademais, o artigo 1.040 inciso III já citado anteriormente, dispõe que "os processos suspensos em primeiro e segundo graus de jurisdição retomarão o curso para julgamento e aplicação da tese firmada pelo tribunal superior".

Cumpre trazer à baila os ensinamentos de Paulo César Conrado (2016, p.533) no que tange aos precedentes e a compensação tributária:

Primeiro de tudo, devemos considerar, até mesmo como homenagem aos valores subjacentes ao art. 19 da Lei $n$. $10.522 / 2002$, que, havendo precedente vinculante caracterizador de um dado pagamento como indébito, não seria o caso sequer de judicilizar o assunto. Reputando-se suficiente, para delimitação da "certeza" do indébito, o precedente vinculativo, estaria autorizado o contribuinte, destarte, a apresentar, de forma "direta", a competente declaração de compensação, oportunizando-se à Administração, na sequência, a certificação, por um lado, do efetivo enquadramento do "caso presente" ao "caso precedente" e, por outro, da liquidez (correção dos valores).

Tal solução, além de pragmaticamente mais fluída, é a que permitiria a acomodação, numa só experiência, das lógicas subjacentes (i) ao sistema de precedentes vinculantes do novo Código e (ii) ao regime de recuperação de indébito por compensação - esse último caracterizado, lembre-se, pela atribuição, em favor do contribuinte, de um protagonismo que lhe assegura o oferecimento de declaração liberatória das duas "contas" confrontadas (crédito e indébito tributários). 


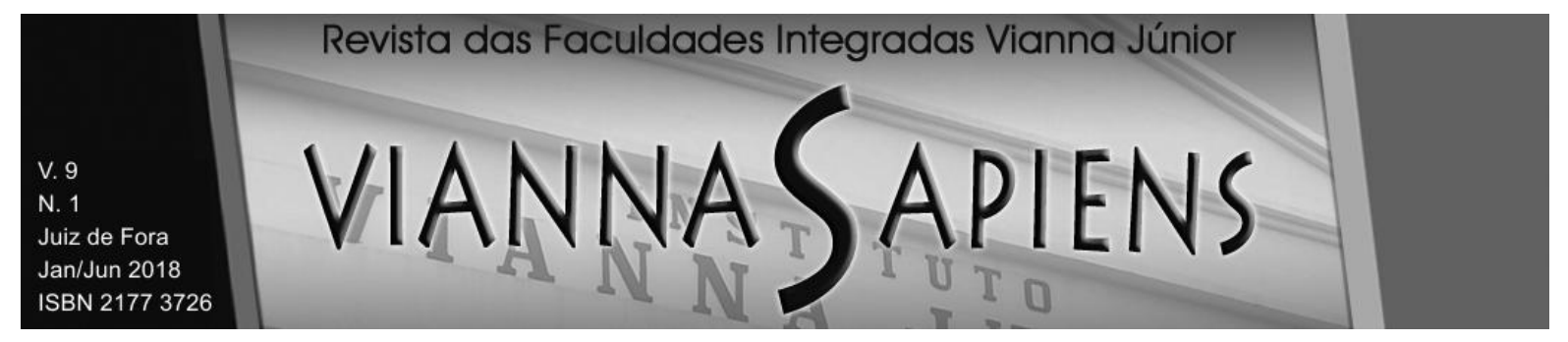

Como se pode depreender das lições do ilustre doutrinador, havendo precedente vinculante que caracterize 0 indébito tributário, sequer haveria necessidade de judicialização, devendo ser oportunizado ao contribuinte a apresentação da declaração de compensação de forma direta, cabendo à administração a homologação, caso seja confirmado o enquadramento da situação geradora do indébito ao caso precedente, bem como ao acerto dos valores compensados.

\section{A RELATIVIZAÇÃo do ALCANCE dA NORMA EXPRESSA NO ARTIGO 170- A DO CÓDIGO TRIBUTÁRIO NACIONAL}

O artigo 170-A do Código Tributário Nacional (BRASIL, 1966) disciplina o momento em que a compensação pode ser feita, qual seja, após o trânsito em julgado da sentença em que se pleiteia o reconhecimento do indébito.

Tal vedação tem justificativa nos casos em que não há uma certeza do direito pleiteado, de forma que a concessão de tutela provisória permitindo a compensação poderá trazer prejuízos ao fisco se a existência do indébito não for confirmada posteriormente.

De maneira mais radical, Hugo de Brito Machado (2017, p. 212-213) defende que o artigo 170-A do Código Tributário Nacional não impede a concessão de liminar nos casos em que os requisitos para a sua concessão estejam presentes:

Há, é certo, decisões judiciais afirmando que em face do art. 170-A, introduzido no Código Tributário Nacional pela Lei Complementar no 104, de 10.1.2001, não se admite medida liminar autorizando a compensação como forma de extinção do crédito tributário. Tais decisões, todavia, não nos parecem acertadas. O art. 170-A veda a compensação que o contribuinte eventualmente pretenda fazer apenas porque, considerando que pagou tributo indevido, ingresse em juízo para obter decisão confirmatória de seu entendimento, vale dizer, decisão considerando que efetivamente ocorreu um pagamento indevido. Não veda o deferimento de medida liminar autorizando a compensação. Disposições de leis ordinárias que 


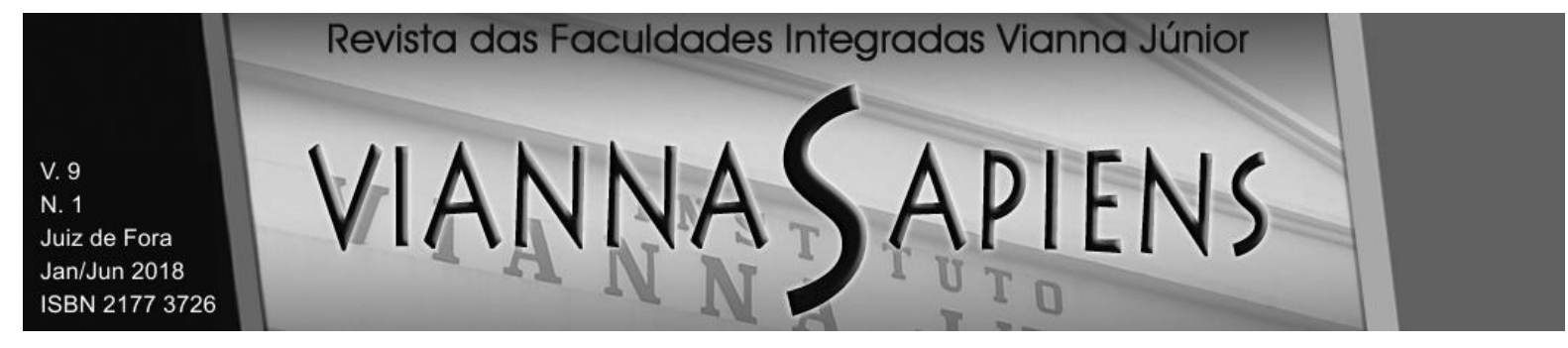

vedam o deferimento de medida liminar para assegurar ao contribuinte 0 direito à compensação padecem de flagrante inconstitucionalidade. Uma vez demonstrado que estão presentes os requisitos para o deferimento da liminar, que por isto mesmo é necessária para assegurar a eficácia da sentença que a final venha a decidir pela existência do direito do contribuinte, o juiz deve deferir a medida, sob pena de estar denegando o direito à jurisdição, constitucionalmente assegurado. Esse entendimento, todavia, por razões óbvias, não é aceito pelas autoridades fazendárias, que geralmente só se preocupam com a arrecadação.

Com a introdução da sistemática de julgamento de recursos repetitivos, faz-se necessária uma interpretação do artigo 170-A conforme a Constituição para que o alcance da norma em comento não atinja os casos em que há precedente favorável ao contribuinte.

A interpretação conforme a Constituição é uma técnica utilizada no âmbito do controle de constitucionalidade das leis. Além disso, pode ser utilizada nos casos em que uma norma possui mais de uma possível interpretação de forma que se escolha aquela em que melhor se aproxime dos anseios constitucionais. Por fim, o método da interpretação conforme a Constituição permite o afastamento do alcance da norma em determinadas situações de fato nos casos em que a sua aplicação represente uma violação a princípios constitucionais.

Nas lições de Barroso (2009, p. 301):

Como técnica de interpretação, o princípio impõe a juízes e tribunais que interpretem a legislação ordinária de modo a realizar, da maneira mais adequada, os valores e fins constitucionais. Vale dizer: entre interpretações possíveis, deve-se escolher a quem tem mais afinidade com a Constituição.

(...)

Como mecanismo de controle de constitucionalidade, a interpretação conforme a Constituição permite que o intérprete, sobretudo o tribunal constitucional, preserve a validade de uma lei que, na sua leitura mais óbvia, seria inconstitucional. Nessa hipótese, o tribunal, simultaneamente, infirma uma das interpretações possíveis, declarando-a inconstitucional, e afirma outra, que compatibiliza a norma com a Constituição. Trata-se de uma atuação "corretiva" que importa na declaração de inconstitucionalidade, sem redução de texto. 


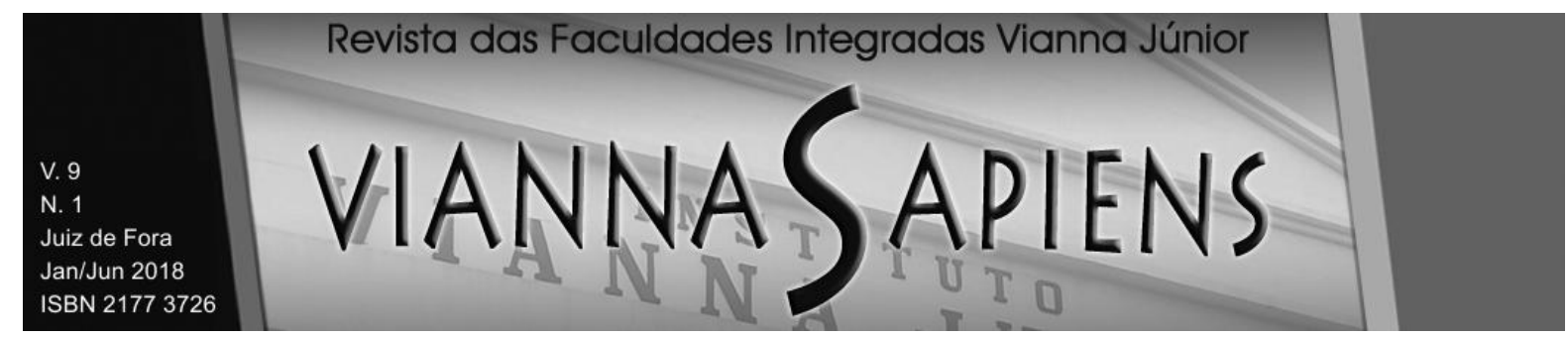

Figura próxima, mas não equivalente, é a da interpretação conforme a Constituição para declarar que uma norma válida e em vigor, não incide sobre determinada situação de fato.

O Supremo Tribunal Federal assim já decidiu (BRASIL, 2006):

I. Recurso extraordinário: alínea "b": devolução de toda a questão de constitucionalidade da lei, sem limitação aos pontos aventados na decisão recorrida. Precedente (RE 298.694, PI. 6.8.2003, Pertence, DJ 23.04.2004). II. Controle incidente de inconstitucionalidade e 0 papel do Supremo Tribunal Federal. Ainda que não seja essencial à solução do caso concreto, não pode o Tribunal - dado o seu papel de "guarda da Constituição" - se furtar a enfrentar o problema de constitucionalidade suscitado incidentemente (v.g. SE 5.206-AgR; MS 20.505). III. Medida provisória: requisitos de relevância e urgência: questão relativa à execução mediante precatório, disciplinada pelo artigo 100 e parágrafos da Constituição: caracterização de situação relevante de urgência legislativa. IV. Fazenda Pública: execução não embargada: honorários de advogado: constitucionalidade declarada pelo Supremo Tribunal, com interpretação conforme ao art. 1--D da L. 9.494/97, na redação que lhe foi dada pela $\operatorname{MPr} 2.180-35 / 2001$, de modo a reduzir-Ihe a aplicação à hipótese de execução por quantia certa contra a Fazenda Pública (C. Pr. Civil, art. 730), excluídos os casos de pagamento de obrigações definidos em lei como de pequeno valor (CF/88, art. 100, §3ํ).

RE 420816, Relator(a): Min. CARLOS VELLOSO, Relator(a) p/ Acórdão: Min. SEPÚLVEDA PERTENCE, Tribunal Pleno, julgado em 29/09/2004, DJ 10-12-2006 PP-00050 EMENT VOL-02255-04 PP00722. (Grifo nosso)

Como se pode depreender do julgado, o Supremo Tribunal Federal decidiu pela restrição do alcance da norma em discussão aos casos de execução por quantia certa contra a Fazenda Pública. Em outras palavras, deu a norma uma interpretação conforme a Constituição delimitando o seu campo de abrangência.

O que se defende no presente trabalho é justamente uma relativização da vedação expressa no artigo 170-A do Código Tributário Nacional por meio de uma interpretação conforme a Constituição, para que o seu alcance não atinja os casos em que o contribuinte tem a seu favor uma decisão em sede de recursos repetitivos.

Ora, se os Tribunais Superiores já decidiram por meio de recurso extraordinário ou especial repetitivo sobre determinada questão, não se justifica a 


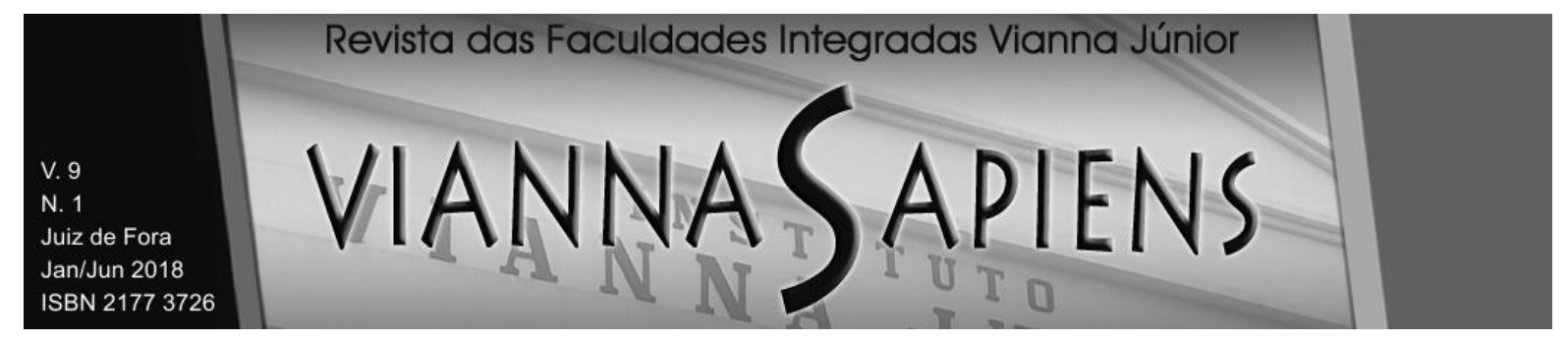

espera do contribuinte para a compensação do indébito tributário somente após o trânsito em julgado da decisão em que se discute a existência do indébito. Isso porque, como dito anteriormente, nos termos do artigo 1.040, inciso III do Código de Processo Civil (BRASIL, 2015), após a decisão dos Tribunais superiores, os processos suspensos nas demais instâncias retornarão o curso para a aplicação da tese firmada, de forma que não poderá haver decisão em sentido contrário.

Outro não é o entendimento de Paulo César Conrado (2016, p. 536) que defende a possibilidade de concessão de tutela provisória fundada em evidência:

Imagine-se, por outro lado, que o feito não se encontre, por razões de procedimento, em fase de julgamento - recebida a inicial, pense-se, o juiz ordenou a citação da Fazenda, nada mais havendo. Vale dizer: não é possível, nessa hipótese, o pronto julgamento. Seria o caso de se impor ao contribuinte, nesse cenário, o ônus de (i) desistir da ação e proceder à compensação com a convocação direta do precedente ou (ii) tolerar o esgotamento do processo para só aí obter a possibilidade de compensar?

Sem recusar a factibilidade de uma dessas alternativas, parece que é o caso de se reconhecer a viabilidade de ao menos uma terceira via, a passar pela emissão de tutela provisória que, fundada em evidência, antecipasse os efeitos da sentença.

Cumpre salientar que o artigo 19 da Lei 10.522/02 (BRASIL, 2002) trouxe a seguinte autorização para Procuradoria-Geral da Fazenda Nacional:

Art. 19. Fica a Procuradoria-Geral da Fazenda Nacional autorizada a não contestar, a não interpor recurso ou a desistir do que tenha sido interposto, desde que inexista outro fundamento relevante, na hipótese de a decisão versar sobre:

(...)

IV - matérias decididas de modo desfavorável à Fazenda Nacional pelo Supremo Tribunal Federal, em sede de julgamento realizado nos termos do art. 543-B da Lei $n^{\circ} 5.869$, de 11 de janeiro de 1973 Código de Processo Civil;

V - matérias decididas de modo desfavorável à Fazenda Nacional pelo Superior Tribunal de Justiça, em sede de julgamento realizado nos termos dos art. 543-C da Lei no 5.869, de 11 de janeiro de 1973 Código de Processo Civil, com exceção daquelas que ainda possam ser objeto de apreciação pelo Supremo Tribunal Federal. 


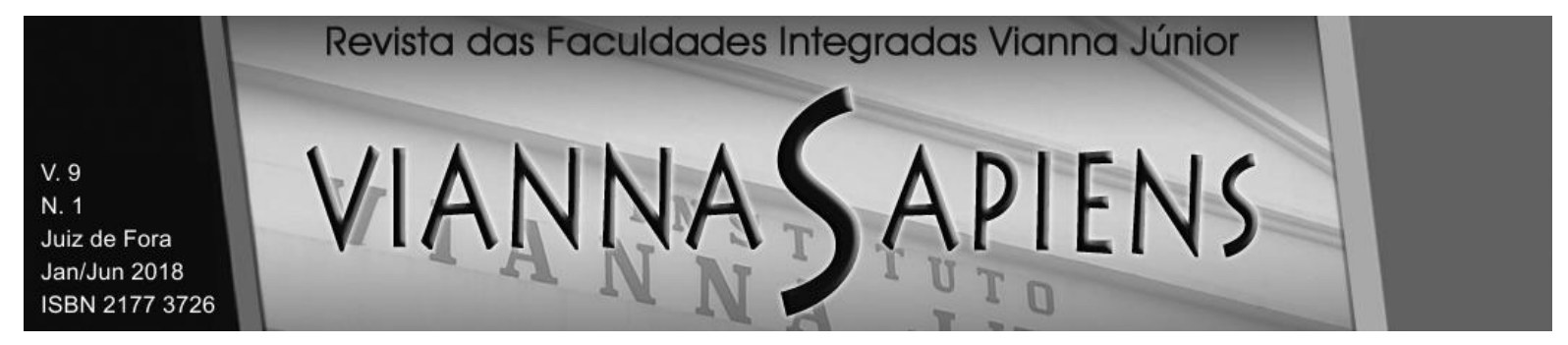

O disposto colacionado autoriza que a Procuradoria-Geral da Fazenda Nacional acate as decisões dos Tribunais superiores em sede de recursos repetitivos quando estas forem desfavoráveis à Fazenda Pública.

Nesse sentido, havendo um parecer da Procuradoria-Geral da Fazenda Nacional reconhecendo a ausência de interesse em prosseguir na discussão quando existe decisão em sede de recurso extraordinário com repercussão geral reconhecida pelo Supremo Tribunal Federal ou recurso especial repetitivo pelo Superior Tribunal de Justiça, o Procurador da Fazenda Nacional que atuar no feito deverá expressamente, nos termos do parágrafo $1^{\circ}$ do artigo 19 da Lei 10.522/02 (BRASIL, 2002):

$\S 1^{\circ}$ Nas matérias de que trata este artigo, o Procurador da Fazenda Nacional que atuar no feito deverá, expressamente:

I - reconhecer a procedência do pedido, quando citado para apresentar resposta, inclusive em embargos à execução fiscal e exceções de pré-executividade, hipóteses em que não haverá condenação em honorários;

II - manifestar o seu desinteresse em recorrer, quando intimado da decisão judicial.

Nessa esteira, havendo precedente firmado em sede de recursos extraordinário e especial repetitivo e parecer da Procuradoria-Geral da Fazenda Nacional, não há margem de interpretação para o Procurador do feito, devendo este reconhecer a procedência do pedido ou manifestar o desinteresse em recorrer.

A Receita Federal do Brasil, por meio da solução de consulta no 119 de 7 de fevereiro de 2017 (BRASIL, 2017), teve o seguinte entendimento:

ASSUNTO: NORMAS GERAIS DE DIREITO TRIBUTÁRIO COMPENSAÇÃO TRIBUTÁRIA. MATÉRIA VINCULANTE. AÇÃO JUDICIAL PRÓPRIA. TRÂNSITO EM JULGADO. REQUISITO. A Secretaria da Receita Federal do Brasil (RFB) encontra-se vinculada aos entendimentos desfavoráveis à Fazenda Nacional firmados sob a sistemática de recurso extraordinário com repercussão geral reconhecida ou de recurso especial repetitivo, a partir da ciência da Nota Explicativa da Procuradoria-Geral da Fazenda Nacional (PGFN), nos termos da Portaria Conjunta PGFN/RFB no 1, de 2014. Em regra, a jurisprudência vinculante autoriza a restituição ou 


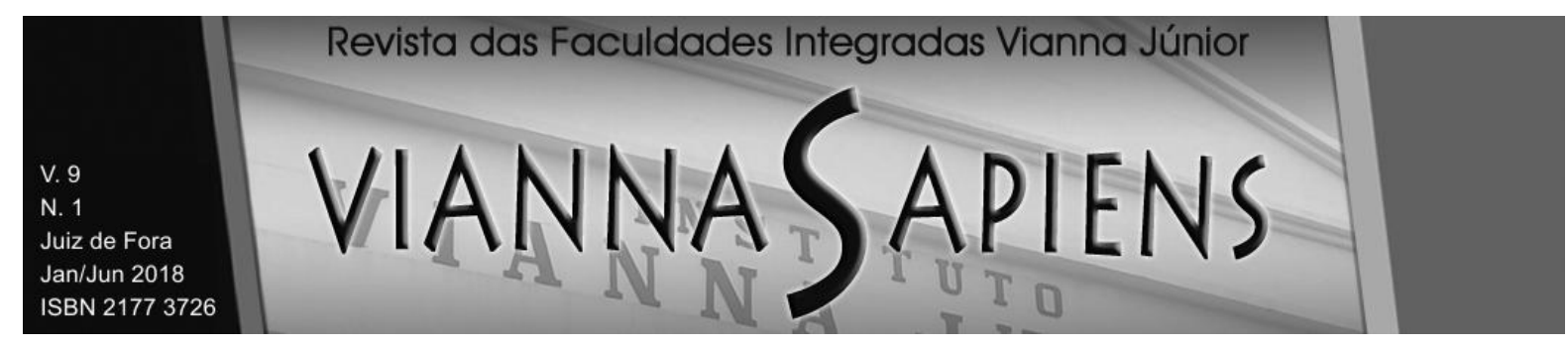

compensação administrativas de tributos recolhidos indevidamente, observados os prazos e procedimentos estabelecidos na legislação. Não obstante, na hipótese em que o direito é postulado mediante ação judicial própria, o contribuinte deve aguardar o trânsito em julgado da decisão judicial, a fim de proceder à execução judicial ou à compensação administrativa. Dispositivos Legais: Art. 170-A do CTN

Pela solução de consulta acima colacionada, fica compreendido que, embora a Receita Federal acate a decisão firmada em sede de recurso extraordinário com repercussão geral reconhecida ou recurso especial repetitivo, essa regra não valerá para o contribuinte que postulou judicialmente o reconhecimento do indébito tributário tendo em vista a vedação expressa no artigo 170-A do Código Tributário Nacional.

Por derradeiro, o Conselho Administrativo de Recursos Fiscais - CARF, (BRASIL, 2018) reconheceu recentemente o direito à compensação tributária antes do trânsito em julgado nos casos de existência de precedente vinculativo:

"PIS. BASE DE CÁLCULO. INCONSTITUCIONALIDADE DO $\S 1^{\circ}$ DO ARTIGO $3^{\circ}$, DA LEI № 9.718/98, QUE AMPLIAVA O CONCEITO DE FATURAMENTO. NÃO INCIDÊNCIA DA CONTRIBUIÇÃO SOBRE RECEITAS NÃO COMPREENDIDAS NO CONCEITO DE FATURAMENTO ESTABELECIDO PELA CONSTITUIÇÃO FEDERAL PREVIAMENTE À PUBLICAÇÃO DA EC № 20/98. A base de cálculo do PIS e da COFINS é o faturamento, assim compreendido a receita bruta das vendas de mercadorias, de serviços e de mercadorias e serviços de qualquer natureza. Inadmissível o conceito ampliado de faturamento contido no $\S 1^{\circ}$ do art. $3^{\circ}$ da Lei $\mathrm{n}^{\circ}$ 9.718/98, uma vez que referido dispositivo foi declarado inconstitucional pelo plenário do Supremo Tribunal Federal (STF).

Diante disso, não poderão integrar a base de cálculo da contribuição as receitas não compreendidas no conceito de faturamento previsto no art. 195, I, b, na redação originária da Constituição Federal de 1988, previamente à publicação da Emenda Constitucional no 20, de 1998.

COMPENSAÇÃO. PEDIDO REALIZADO ANTES DO TRÂNSITO EM JULGADO EM FAVOR DO CONTRIBUINTE. QUESTÃO DE CONTEÚDO QUE DEVE SE SOBREPOR À FORMA. PREVALÊNCIA DA RATIO DECIDENDI DE PRECEDENTE PRETORIANO DE CARÁTER VINCULANTE COM A ADEQUAÇÃO DO DISPOSTO NO ART. 170-A DO CTN. 


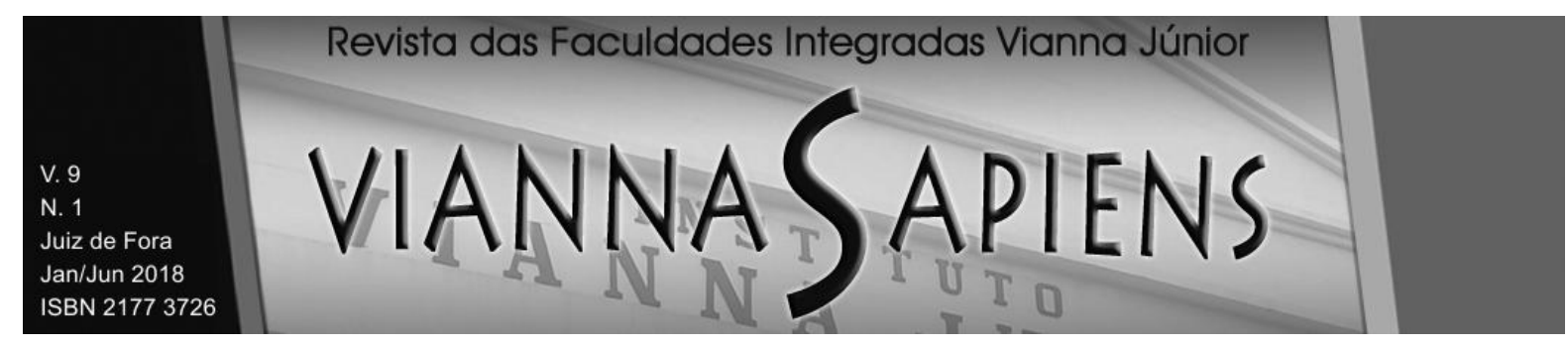

Embora o pedido de compensação perpetrado pelo contribuinte tenha se contraposto à literalidade do art. 170-A do CTN, ao final do processamento judicial a lide por ele proposta foi julgada procedente, com base em precedente vinculante do STF. (RE n. 357.950) o que, por sua vez, faz convocar em seu favor o disposto nos artigos 489, $\S$ 10, inciso VI, 926 e s.s., todos do CPC/2015, bem como o disposto no art. $62, \S 1^{\circ}$, inciso II, alínea "b" do RICARF e, ainda, ao prescrito no art. 2o, inciso $V$ da Portaria PGFN n. 502/2016. Recurso voluntário provido para sujeitar a Administração Pública ao precedente vinculante do STF (RE n. 357.950). Pedido de compensação a ser analisado pela instância competente apenas para fins de apuração quanto a adequação do montante compensado". (Número do Processo : 10880.906342/2008-96, Data da Sessão 22/03/2018, Acórdão 3402-005.025)

Resta patente que o artigo 170-A do Código Tributário Nacional deve ser interpretado de forma a não prejudicar o contribuinte que tenha uma decisão favorável em sede de recurso repetitivo, mas que optou por pleitear o seu direito por via judicial. Ora, reconhecer o direito a compensação tributária de forma imediata nesse caso, somente para o contribuinte que não ajuizou sua demanda contra a Fazenda, é violar o princípios da isonomia e da duração razoável do processo.

\section{CONCLUSÃO}

O artigo 170-A do Código Tributário Nacional foi editado em um período anterior à criação da sistemática de julgamento de recursos extraordinário e especial repetitivos. Nessa esteira, sua aplicação só se justifica nos casos em que o contribuinte pleiteia o reconhecimento do indébito sem que haja uma certeza quanto ao reconhecimento do seu direito.

O artigo 5o inciso LXXXVIII introduzido pela Emenda Constitucional $n^{-}$ 45/2004 prevê como direito fundamental a duração razoável do processo e os meios de garantia da celeridade de sua tramitação. Nesse sentido, a Lei 11.418/06 introduziu no ordenamento pátrio os institutos da repercussão geral no Supremo Tribunal Federal e dos recursos repetitivos no Superior Tribunal de Justiça. Por meio desse mecanismo, que foi introduzido no novo Código de Processo Civil nos artigos 


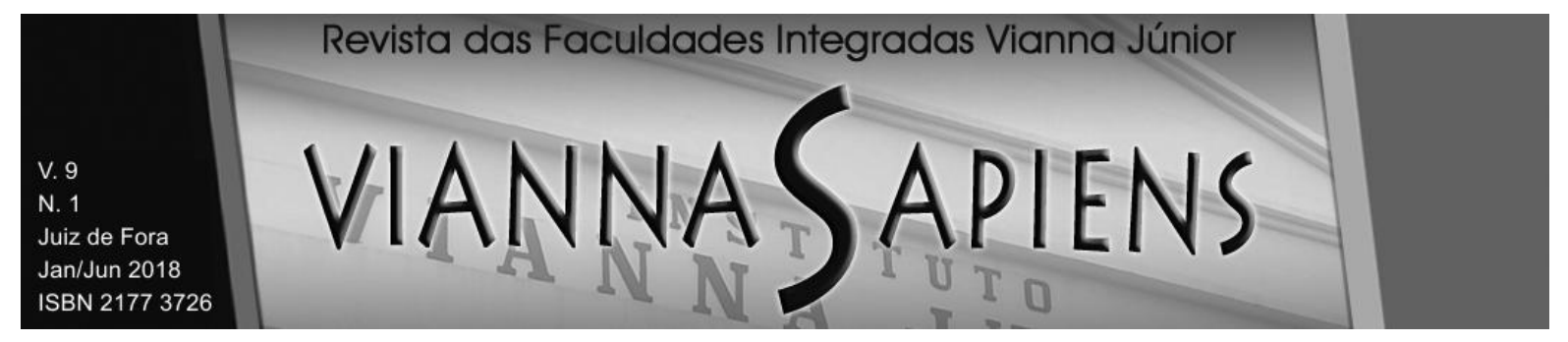

1.036 a 1.041, sempre que houver multiplicidade de recursos extraordinários ou especiais com fundamento em idêntica questão de direito, aplica-se o mecanismo do julgamento dos recursos extraordinário e especiais repetitivos por meio da afetação de recursos paradigma.

Nessa esteira, a decisão dos Tribunais Superiores representa um precedente que deve ser aplicado nos processos que estejam tramitando nas instâncias inferiores. Assim, por meio do precedente, possibilita-se a observância dos princípios da isonomia e celeridade processual. Além disso, o precedente favorável ao contribuinte representa uma certeza do direito que viabiliza de forma imediata a antecipação dos efeitos da sentença, já que esta deverá seguir a tese firmada no julgamento dos recursos extraordinário e especial repetitivos.

$\mathrm{O}$ tratamento diferenciado que tem sido dado ao contribuinte que pleiteia o reconhecimento do indébito pelas vias judiciais, fere os princípios da isonomia e celeridade processual, tendo em vista que a ele é aplicada a vedação a compensação tributária antes do trânsito em julgado em qualquer caso. Já o contribuinte que pleiteia a compensação nas vias administrativas, obtém de forma célere o reconhecimento do seu direito quando houver tese favorável firmada pelos Tribunais Superiores, não havendo óbice para a compensação imediata.

Nesse diapasão, o artigo 170-A do Código Tributário Nacional deve ser interpretado conforme a Constituição a fim de afastar a sua incidência nos casos em que há precedente favorável firmado em sede de julgamento de recursos extraordinário e especial repetitivos, possibilitando que o contribuinte obtenha a antecipação dos efeitos da sentença, garantindo a compensação imediata do indébito tributário. 


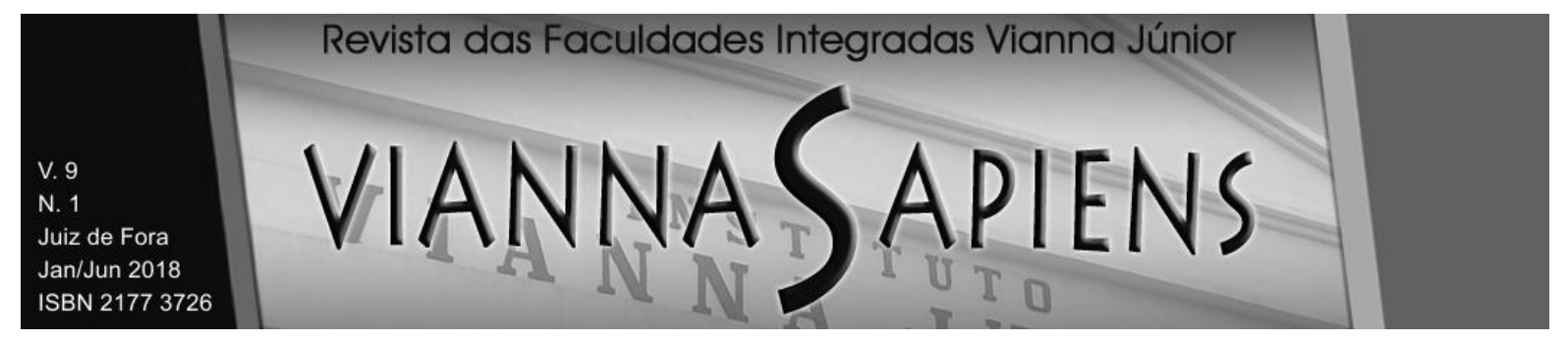

\title{
THE NEED FOR INTERPRETATION ACCORDING TO THE CONSTITUTION OF ARTICLE 170-A OF THE NATIONAL TAX CODE
}

\begin{abstract}
Article 170-A introduced in the National Tax Code by Complementary Law 104/2001 expressly prohibits tax compensation before a final decision is rendered in which the recognition of the claim is sought. In other words, said article does not allow an injunction to offset tax credits in mandated actions or urgent relief in the ordinary shares of claim. In this vein, this paper aims to demonstrate the need for an interpretation of Article 170-A according to the Federal Constitution in cases in which the taxpayer has a decision in favor of a general repercussion or repetitive appeal, and it is no longer justified to wait the final res judicata and then offset the tax liability. The methodology used was the bibliographical and documentary research based on updated magazines and books, as well as in jurisprudence and national legislation. Finally, it was concluded that it is possible to grant the anticipation of the effects of the judgment in cases in which the taxpayer has a precedent of a binding nature.
\end{abstract}

KEYWORDS: ARTICLE 170-A. NACIONAL TAX CODE. TAX COMPENSATION.

\section{REFERÊNCIAS}

ABRAHAM, Marcus. Common Law e os precedentes vinculantes na jurisprudência tributária. Revista do Programa de Pós-Graduação em Direito da UFC, v.34, n.1, jan/jun.2014, p. 145-167.

ARAÚJJO, Juliana Furtado Costa. O precedente no novo Código de Processo Civil e suas implicações tributárias. In: CONRADO, Paulo Cesar e ARAÚJO, Juliana Furtado Costa. (Orgs). O Novo CPC e seu impacto no Direito Tributário. São Paulo: Fiscosoft, 2016. 


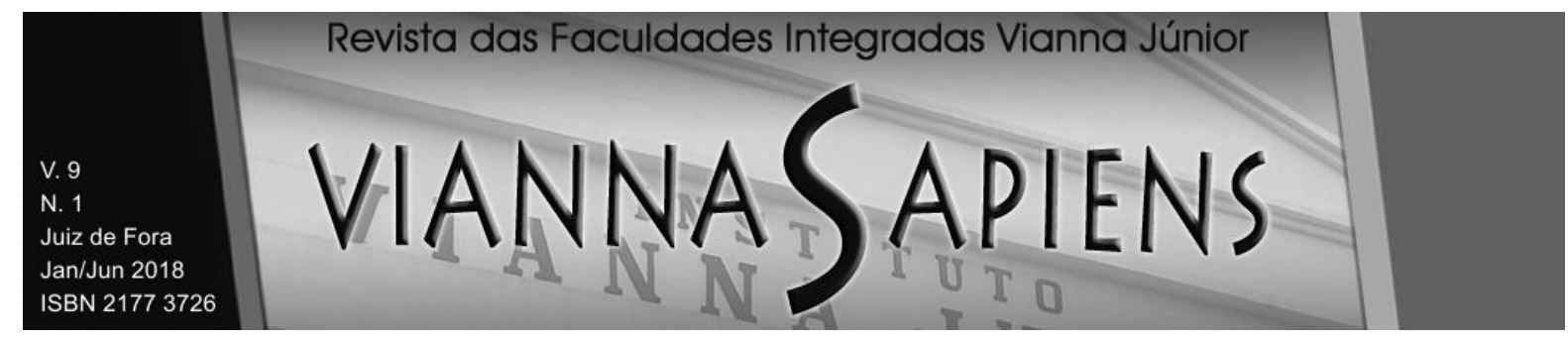

BARROSO, Luís Roberto Barroso. Curso de Direito Constitucional

Contemporâneo: Os conceitos fundamentais e a construção do novo modelo. São Paulo: Saraiva, 2009.

BRASIL. Lei n. 5.172, de 25 de outubro de 1966. Dispõe sobre o Sistema Tributário Nacional e institui normas gerais de direito tributário aplicáveis à União, Estados e Municípios. Diário Oficial [da] República Federativa do Brasil. Disponível em < http://www.planalto.gov.br/ccivil 03/leis/L5172Compilado.htm > Acesso em 10 mar. 2017.

BRASIL. Constituição Federal da República Federativa do Brasil, de 05 de outubro de 1988. Diário Oficial [da] República Federativa do Brasil. Disponível em < http://www.planalto.gov.br/ccivil 03/constituicao/constituicaocompilado.htm > Acesso em 10 mar. 2017.

BRASIL. Lei n. 8.383, de 30 de dezembro de 1991. Institui a Unidade Fiscal de Referência, altera a legislação do imposto de renda e dá outras providências. Diário Oficial [da] República Federativa do Brasil. Disponível em < http://www.planalto.gov.br/ccivil 03/leis/L8383.htm > Acesso em 13 Jun. 2017.

BRASIL. Lei n. 9.430, de 27 de dezembro de 1996. Dispõe sobre a legislação tributária federal, as contribuições para a seguridade social, o processo administrativo de consulta e dá outras providências. Diário Oficial [da] República Federativa do Brasil. Disponível em < http://www.planalto.gov.br/ccivil 03/leis/L9430.htm > Acesso em 13 Jun. 2017.

BRASIL. Lei Complementar n. 104, de 10 de Janeiro de 2001. Altera dispositivos da Lei no 5.172, de 25 de outubro de 1966 - Código Tributário Nacional. Diário Oficial [da] República Federativa do Brasil. Disponível em < http://www.planalto.gov.br/ccivil 03/leis/LCP/Lcp104.htm > Acesso em 10 mai. 2017.

BRASIL. Lei n. 10.406, de 10 de janeiro de 2002. Institui o Código Civil. Diário Oficial [da] República Federativa do Brasil. Disponível em < http://www.planalto.gov.br/ccivil 03/leis/2002/L10406.htm > Acesso em 13 Jun. 2017. 


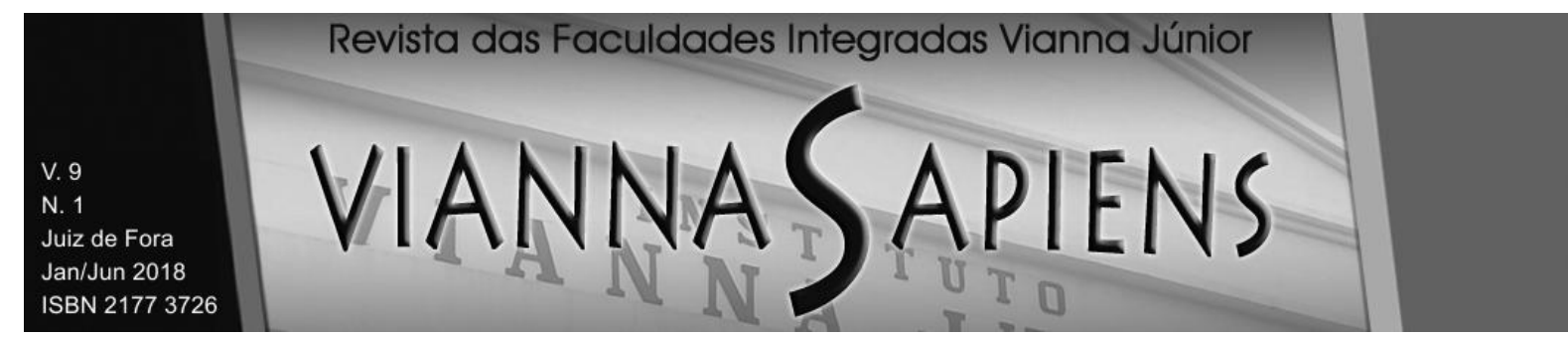

BRASIL. Lei n. 10.522, de 19 de julho de 2002. Dispõe sobre o Cadastro Informativo dos créditos não quitados de órgãos e entidades federais e dá outras providências. Diário Oficial [da] República Federativa do Brasil. Disponível em < http://www.planalto.gov.br/ccivil 03/leis/2002/L10522.htm > Acesso em 13 Jun. 2017.

BRASIL. Emenda Constitucional n. 45, de 30 de dezembro de 2004. Altera dispositivos dos arts. 5ㅇ, 36, 52, 92, 93, 95, 98, 99, 102, 103, 104, 105, 107, 109, 111, 112, 114, 115, 125, 126, 127, 128, 129, 134 e 168 da Constituição Federal, e acrescenta os arts. 103-A, 103B, 111-A e 130-A, e dá outras providências. Diário Oficial [da] República Federativa do Brasil. Disponível em < http://www.planalto.gov.br/ccivil 03/constituicao/emendas/emc/emc45.htm $>$ Acesso em 13 Jun. 2017.

BRASIL. Supremo Tribunal Federal. Recurso Extraordinário n. 420816. Relator. Min. Sepúlveda Pertence. DJ: 10/12/2006. Disponível em < http://www.stf.jus.br/portal/processo/verProcessoAndamento.asp?numero $=420816 \& \mathrm{C}$ lasse $=\mathrm{RE} \&$ codigoClasse $=0$ \&origem $=\mathrm{JUR} \&$ recurso $=0$ \&tipoJulgamento $=\mathrm{M}>$ Acesso em: 13 jun. 2017.

BRASIL. Lei n. 11.418, de 19 de dezembro de 2006. Acrescenta à Lei no 5.869 , de 11 de janeiro de 1973 - Código de Processo Civil, dispositivos que regulamentam o $\S$ 3ํdo art. 102 da Constituição Federal. Diário Oficial [da] República Federativa do Brasil. Disponível em < http://www.planalto.gov.br/ccivil 03/ ato20042006/2006/lei/l11418.htm > Acesso em 13 Jun. 2017.

BRASIL. Lei n. 11.457, de 16 de março de 2007. Dispõe sobre a Administração Tributária Federal; altera as Leis n. 10.593, de 6 de dezembro de 2002, 10.683, de 28 de maio de 2003, 8.212, de 24 de julho de 1991, 10.910, de 15 de julho de 2004, o Decreto-Lei n. 5.452, de $1^{\circ}$ de maio de 1943, e o Decreto n. 70.235, de 6 de março de 1972; revoga dispositivos das Leis n. 8.212, de 24 de julho de 1991, 10.593, de 6 de dezembro de 2002, 10.910, de 15 de julho de 2004, 11.098, de 13 de janeiro de 2005, e 9.317, de dezembro de 1996; e dá outras providências. Diário Oficial [da] República Federativa do Brasil. Disponível em < http://www.planalto.gov.br/ccivil 03/ ato2007-2010/2007/lei/l11457.htm > Acesso em 13 Jun. 2017. 


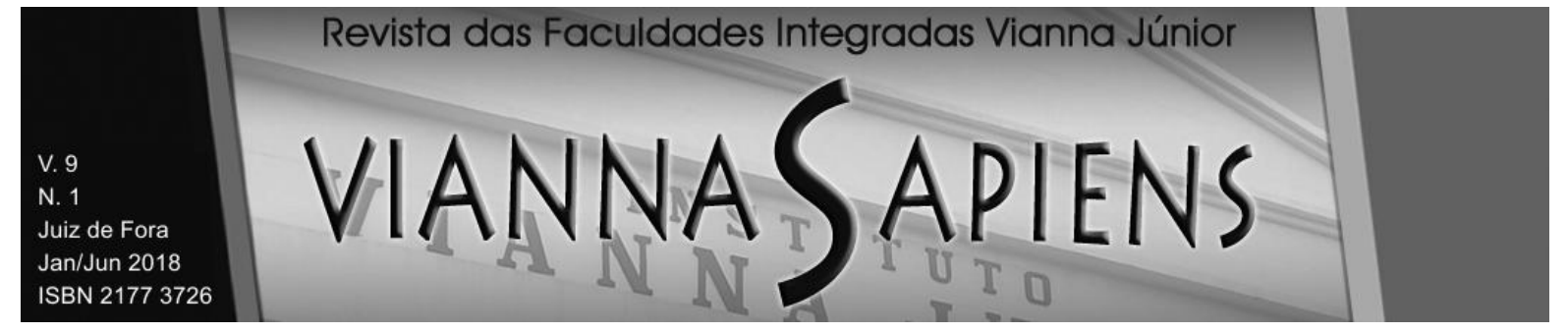

BRASIL. Lei n. 13.105, de 16 de março de 2015. Código de Processo Civil. Diário Oficial [da] República Federativa do Brasil. Disponível em < http://www.planalto.gov.br/ccivil 03/ ato2015-2018/2015/lei//13105.htm > Acesso em 10 mar. 2017.

BRASIL, Receita Federal do. Solução de Consulta n. 119, de 07 de fevereiro de 2017. Dispõe sobre Normas Gerais de Direito Tributário. Diário Oficial [da] República Federativa do Brasil. Disponível em < http://normas.receita.fazenda.gov.br/sijut2consulta/link.action?visao=anotado\&idAto= $\underline{80397}$ > Acesso em 13 Jun. 2017.

BRASIL. Conselho Administrativo de Recursos Fiscais. Recurso Voluntário $\mathbf{n}$. 10880.906342/2008-96. Relator Diego Diniz Ribeiro. DJ: 23/03/2018. Disponível em https://carf.fazenda.gov.br/sincon/public/pages/ConsultarJurisprudencia/listaJurispru dencia.jsf?idAcordao $=7201336$

CONRADO, Paulo César. O Novo Código de Processo Civil e a Compensação Tributária. Parahyba Judiciária, v.10, n.10, 2016, p. 515-538.

DINIZ, Maria Helena. Curso de direito civil brasileiro: teoria geral das obrigações. v. 2. 22. ed. São Paulo, Saraiva, 2007.

MACHADO. Hugo de Brito. Curso de Direito Tributário. 38ª Ed., São Paulo: Malheiros Editores, 2017.

MELO, José Eduardo Soares De. Curso de Direito Tributário. $7^{a}$ Ed., São Paulo: Dialética, 2007.

Recebido em 07/03/2018

Publicado em 13/08/2018 